\title{
IMPLIKASI POLITIK KEBIJAKAN HUKUM PIDANA DALAM UUPLH
}

\author{
David Aprizone Putra \\ Fakultas Hukum Universitas Muhammadiyah Bengkulu \\ Jl. Bali, Kp. Bali, Tlk. Segara, Kota Bengkulu \\ Email : davidaprizonputra@gmail.com
}

\begin{abstract}
Political Law is one of the discourses that control the existence of law. One of the realm of law that has recently received the spotlight and serious attention. Particularly related to the legal political option is the environment law that increasingly strong day include criminal law enforcement in law enforcement. There are some weak things that then have negative implications, against the enforcement of environmental laws related to the lack of cautious political choice. Since 1982 in Law No. 4 of 1982 on the Principles of Environmental Management which was changed in 1997 into Law No. 27 of 1997 on Environmental Management, the legal politics of criminal law policy has been conducted, that the criminal law policy in the realm of the environment is already a choice of legal politics in the realm of environmental law. Law Number 32 Year 2009 About PPLH as the latest generation, adds Chapter XV of the Criminal Code in its charge of 23 Articles. Law Number 32 Year 2009 contains a much more complete criminal provision than Law Number 23 Year 1997. Although there is still much to be fixed on the provisions of Law Number 32 Year 2009. Base on research shows that there are special procedural laws that regulate formal law enforcement. It is based on the principle of ultimum remedium which means that the implementation of the criminal law must wait until the effectiveness of administrative law is upheld. To minimize obstacles in enforcing environmental laws which are sometimes used by political elites to seek profit, formal laws against environmental crimes should be set up specifically with the Act.
\end{abstract}

\section{Keywords: Policy Implications, Political Enforcement of Criminal Law, Environmental Law Enforcement}

\begin{abstract}
Abstrak
Politik Hukum merupakan salah satu diskursus yang memegang kendali terhadap eksistensi hukum.Salah satu ranah hukum yang belakangan ini mendapat sorotan dan perhatian serius. Khususnya terkait opsi politik hukum yaitu ranah hukum lingkungan yang semakin hari semakin kuat memasukkan penegakan hukum pidana dalam penegakan hukumnya. Ada beberapa hal yang lemah yang kemudian berimplikasi negatif, terhadap penegakan hukum lingkungan terkait pada pilihan politik hukum yang kurang hati-hati. Sejak Tahun 1982 dalam Undang-Undang Nomor 4 Tahun 1982 Tentang Pokok-Pokok Pengelolaan Lingkungan Hidup yang kemudian dirubah pada tahun 1997 menjadi Undang-Undang Nomor 27 Tahun 1997 tentang Pengelolaan Lingkungan Hidup, politik hukum mengenai kebijakan hukum pidana telah dilakukan, bahwa kebijakan hukum pidana dalam ranah lingkungan hidup memang sudah menjadi pilihan politik hukum dalam ranah hukum lingkungan. UU Nomor 32 Tahun 2009 Tentang PPLH sebagai generasi terbaru, menambahkan Bab XV KUHpidana dalam muatannya sebanyak 23 Pasal. Undang-Undang Nomor 32 Tahun 2009 memuat ketentuan pidana yang jauh lebih lengkap dibandingkan Undang-Undang Nomor 23 Tahun 1997. Kendati masih banyak yang harus dibenahi pada ketentuan Undang-Undang Nomor 32 Tahun 2009. Dalam penelitian menunjukan bahwa ada hukum acara khusus yang mengatur mengenai penegakan hukum formal. Ini didasarkan pada asas ultimum remedium yang memiliki arti
\end{abstract}


bahwa pelaksanaan terhadap hukum formal pidana harus menunggu hingga tidak efektifnya hukum administrasi ditegakan. Untuk meminimalisir hambatan dalam penegakan hukum lingkungan dimana kadang dimanfaatkan elit politik untuk mencari keuntungan, maka hukum formal terhadap kejahatan lingkungan harus dibentuk khusus dengan Undang-Undang.

\section{Kata kunci: Implikasi Kebijakan, Penegakan Politik Hukum Pidana, Penegakan Hukum Lingkungan Hidup}

\section{A. PENDAHULUAN}

Lingkungan hidup yang baik dan sehat merupakan hak asasi setiap warganegara Indonesia sebagaimana diamanatkan dalam Pasal 28H ayat (1) Undang-Undang Dasar Negara Republik Indonesia Tahun 1945 (selanjutnya disebut UUD 1945). ${ }^{1}$ Pemanasan global yang semakin meningkat mengakibatkan perubahan iklim sehingga memperburuk penurunan kualitas lingkungan hidup maka perlu dilakukan perlindungan dan pengelolaan lingkungan hidup.

Pembahasan masalah lingkungan membawa kita pada masalah yang rumit, keterkaitan beberapa faktor dan masalah serta persepsi baru yang mengharuskan kita untuk meninggalkan pandangan-pandangan yang sudah dianggap usang (obstinate) ${ }^{2}$ Perkembangan ini dengan segera membawa kita pada suatu persoalan pokok penting, yaitu cara bagaimana sistem hukum harus mampu menjawab secara efektif persoalan yang timbul dari benturan-benturan kepentingan yang timbul dari pemanfaatan lingkungan yang terjadi akhir-akhir ini. ${ }^{3}$ Maka Artinya bahwa pemerintah harus mampu membuat suatu pilihan politik hukum yang mampu menciptakan sistem hukum lingkungan yang kuat dan efektif dalam menyelesaikan setiap permasalahannya.

Undang-Undang Nomor 4 Tahun 1982 Tentang Ketentuan-Ketentuan Pokok Pengelolaan Lingkungan Hidup (UUPPLH1982) adalah awal untuk penegakan hukum lingkungan hidup di Indonesia. UUPPLH1982 memuat prinsip-prinsip pengelolaan lingkungan hidup yang berfungsi memberikan arahan (direction) bagi sistem hukum lingkungan nasiona., Setelah 15 Tahun akhirnya undang-undang ini pun dicabut karena dianggap kurang sesuai agar terwujud pembangunan berkelanjutan seperti apa yang dicita-citakan Undang-Undang Nasional Tentang Pengelolaan LingkunganHidup Undang-Undang Nomor 23 Tahun 1997 (selanjutnya disebut UUPPLH Tahun 1997) dan diganti lagi oleh Undang-Undang Nomor 32Tahun 2009 (selanjutnya disebut UUPPLH2009) dengan alasan agar lebih menjamin kepastian hukum dan memberikan perlindungan terhadap hak setiap orang untuk mendapatkan lingkungan hidup yang baik dan sehat, melalui penjatuhan sanksi pidana yang cukup berat didalam UndangUndang Nomor 32 Tahun 2009.

UUPLH 1992 membuat penegakan atas hukum pidana dalam pidana lingkungan hidup adalah rendah karena UUPLH 1992 menempatkan hukuman pidana sebagai ultimum

\footnotetext{
1 Pasal 28H ayat (1) UUD 1945 : "Setiap orang berhak hidup sejahtera lahir dan batin, bertempat tinggal, dan medapatkan lingkungan hidup baik dan sehat serta berhak memperoleh pelayanan kesehatan"

2 Daud Silalahi, Masalah Pengelolaan Lingkungan Hidup, Edisi Ketiga, Alumni, Bandung, 2001, hlm. 1 3 Ibid
} 
remidium. Penjelasan asas ultimum remidium dalam UUPLH Tahun 1992 bahkan tidak jelas dan tegas. Asas ini hanya tertuang dalam penjelesan umum. Padahal penjelasan umum merupakan media untuk memperjelas makna yang ada dalam konsideran Undang-Undang, baik mengenai landasan filosofis, landasan yuridis maupun landasan sosiologis. ${ }^{4}$

Kelemahan konsep asas subsidiaritas dalam perumusanpada UUPPLH 1982 mengakibatkanpenghapusan asas subsidiaritas. Dalam UUPPLH 1997 asas subsiaritas diganti dengan asas ultimumremedium, yang dibatasi terhadap delik formiltertentu, yaitu pelanggaran baku mutu air limbah, emisi, dan gangguan saja. Selebihnya terhadap delik formil hukum pidana difungsikan sebagai premum remedium. Terdapat minimal empat dimensi yang dapat mempengaruhi kualitas penegakan hukumn lingkungan yaitu adanya Undang-undang lingkungan secara nyata, pelanggar hukumnya sendiri, korban (masyarakat), dan aparat penegak hukum, dimana keempat dimensi tersebut bersifat saling mempengaruhi dan berlangsung dalam satu wadah struktur politik, sosial, ekonomi,dan budaya pada keadaan tertentu. ${ }^{5}$

Sebenarnarnya, dalam suatu peraturang perundang-undangan, pengertian pemidanaan sangat penting. Mengingat pentingnya hal ini, UUPLH 2009 memasukan ketentuan pidana ini dalam muatan materinya. Upaya pemerintah dan legislator untuk memperbaiki undang undang ini dengan kemudian mengakomodir ketentuan pidana dan melengkapinya dalam UUPLH Tahun 2009. UUPLH Tahun 2009 memasukan ketentuan pidana pada Bab khusus yaitu BAB VX yang tertuang dalam Pasal 97 hingga Pasal 120 (muatan sebanyak 23 pasal). Permasalahan lingkungan merupakan permasalahan yang kompleks dan menarik untuk dikaji mendalam, dalam penelitian ini penulis akan mengkaji implikasi politik hukum yang dipilih UUPPLH terkait pengaturan penegakan hukum pidana terhadap penegakan hukum lingkungan di Indonesia untuk saat ini dan masa yang akan datang.

Berdasarkan latar belakang keadaan tersebut, melalui metode penelitian yuridis normatif dengan melakukan kajian pustaka dan telaah terhadap kasus yang ada, permasalahan yang dapat diangkat dalam penelitian ini adalah : a) Bagaimana implikasi politik penegakan hukum pidana dalam Undang-Undang Nomor 32 Tahun 2009 Tentang perlindungan dan pengelolaan lingkungan hidup terhadap upaya penegakan hukum lingkungan hidup Indonesia saat ini; serta b) Bagaimana implikasi politik penegakan hukum pidana dalam Undang-Undang Nomor 32 Tahun 2009 terkait RUU KUHP terhadap upaya penegakan hukum lingkungan hidup Indonesia pada masa akan datang.

\section{B. PEMBAHASAN}

1. Implikasi Politik Penegakan Hukum Pidana dalam Undang-Undang Nomor 32 Tahun 2009 Tentang Perlindungan dan Pengelolaan Lingkungan Hidup terhadap Upaya Penegakan Hukum Lingkungan Hidup Indonesia Saat Ini.

\footnotetext{
${ }^{4}$ Syahrul Machmud, Penegakan Hukum LingkunganIndonesia, Graha Ilmu, Yogyakarta, 2011,hlm. 169.

${ }^{5}$ I.S Susanto, Pemahaman Kritis Terhadap Realita Sosial,MajalahMasalah-Masalah Hukum, Nomor 9 Tahun1992
} 
Dalam pandangan Malthus dalam postulatnya meramalkan bahwa kemajuan penduduk untuk bertambah secara kuantitas adalah lebih besar daripada kesanggupan sumber alam menyediakan kebutuhan pangan manusia, sehingga secara matematis dapat dijelaskan pertumbuhan pangan mengikuti deret hitung. ${ }^{6}$ Masalah lingkungan hidup di Indonesia semakin hari semakin mengalami peningkatan sekaligus kompleksitas yang luar biasa pelik persolannya. Lingkungan hidup kalah melawan kekuatan pembangunan yang selalu saja menjadikan tujuan ekonomi diatas segala-galannya. Paradigma kalangan pemerintahan berpendirian bahwa tujuan-tujuan pembangunan ekonomi tidak perlu dipertentangkan dengan usaha-usaha melestarikan lignkungan hidup. ${ }^{7}$

Langkah awal yang kemudian menjadi pondasi berpijak sistem hukum lingkungan untuk menjamin tidak terjadinya kerusakan lingkungan yang semakin parah adalah pilihan politik hukum bagi perkembangan lingkungan diruang kedaulatan negeri ini, bentuknya mau diarahkan kemana direksinya, mau dijadikan seperti apa posturnya, adalah merupakan tanggungjawab pengambil kebijakan dalam keputusan terkait pembentukan lingkungan berkelanjutan. Terkait hal tersebut penulis melihat pandangan Prof.Daud Silalahi yang menyatakan bahwa untuk menjaga lingkungan hidup Indonesia agar terjamin kelestarian serta mutunya adalah dengan memiliki sistem hukum yang kuat. Sistem hukum yang mampu menjawab serta menyelesaikan setiap permasalahan hukum yang terjadi. ${ }^{8}$

Pilihan politik hukum kita terhadap penegakan hukum lingkungan adalah dengan dimasukannya penegakan hukum pidana didalam sistem penegakan hukum lingkungan, dan. berikut penulis jabarkan secara yuridis terkait dengan pilihan politik hukum tersebut. Bahwa Sejak dikeluarkannya UUPPLH Tahun 2009 yang menggantikan UUPLH Tahun 1997 maka fungsi sebagai Undang-Undang induk umbrella provisions melekat pada UUPPLH 2009. UUPPLH membawa perubahan mendasar dalam pengaturan pengelolaan lingkungan hidup di Indonesia. ${ }^{9}$ Jika dicermati terdapat beberapa perbedaan pengaturan antara UUPPLH 1997 dan UUPPLH 2009. Pertama, UUPPLH 1997 merumuskan tindak pidana sebagai tindakan yang mengakibatkan pencemaran dan/atau perusakan lingkungan hidup (sebagaimana diatur dalam Pasal 41), sedangkan UUPPLH 2009 merumuskan tindak pidana yaitu sebagai tindakan yang mengakibatkan dilampauinya baku mutu udara ambien, baku mutu air, baku mutu air laut, atau kriteria baku kerusakan lingkungan hidup (sebagaimana diatur dalam Pasal 98). Kedua, UUPPLH 1997 merumuskan pidana dengan pidana maksimum, sedangkan UUPPLH 2009 merumuskan pidana dengan minimum dan maksimum. Ketiga, UUPPLH 2009 mengatur mengenai hal-hal yang tidak di atur dalam UUPPLH 1997 yaitu di antaranya pemidanaan bagi pelanggaran baku mutu (sebagaimana diatur dalam Pasal 100), perluasan alat bukti, keterpaduan penegakan hukum pidana, dan pengaturan tindak pidana korporasi.

\footnotetext{
${ }^{6}$ Donella H. Meadows, Batas-batas pertumbuhan, diterjemahkan oleh : Masri Maris, Gramedia, Jakarta, 1980, hlm. 14

${ }^{7}$ Muhammad Erwin,Hukum Lingkungan : dalam sistem kebijaksanaan pembangunanLingkungan HidupEdisi Ketiga, Refika Aditama, Bandung, 2007, hlm. 202

${ }^{8}$ Penulis sampaikan pada bagian latar belakang, tepatnya pada paragraf 2 halaman 1

${ }^{9}$ Edra Satmaidi, "Politik Hukum Pengelolaan LingkunganHidup Di Indonesia Setelah Perubahan UndangUndangDasar 1945”, Jurnal Konstitusi, Vol. 4 No. 1 Tahun 2011,FH Universitas Riau, hlm. 69-81
} 
Pada bagian penjelasan UUPPLH Tahun 2009 telah dijabarkan yaitu mengenai perbedaan UUPPLH Tahun 2009 dengan UUPPLH Tahun 1997 yaitu adanya tambahan dan penguatan pada UUPPLH Tahun 2009 mengenai prinsip-prinsip perlindungan dan pengelolaan lingkungan hidup yang didasari kepada good governance pada setiap proses rumusan dan penerapan pencegahan terhadap pencemaran maupun kerusakan lingkungan hidup dan penegakan hukum serta penanggulangannya wajib diintegrasikan terhadap aspek partisipasi, transparansi, keadilan dan akuntabilitas.

Penjelasan umum UUPPLH2009 memandang bahwa hukum pidana terhadap kejahatan lingkungan hidup sebagai upaya terakhir (ultimum remedium) bagi tindak pidana formil tertentu, dan bagi tindak kejahatan maupun pidana lainnya yang diatur selain Pasal 100 UUPPLH Tahun 2009, asas ultimum remedium tidak diberlakukan. Asas yang diberlakukan adalah asas premium remedium (asas mendahulukan pelaksanaan penegakan hukum pidana). Asas ultimum remedium dapat digunakan namun sebagai pilihanhukum yang terakhir.

Asas subsidaritas yang dimiliki oleh UUPPLH 1997 akhirnya tergantikan oleh asas ultimum remedium. Menurut penulis kedua asas ini adalah sama, hanya terdapat sedikit perbedaan yaitu dalam asas ultimum remedium dipertegas bahwa keberadaan asas ini hanya untuk diberlakukan pada delik formal semata, bahkan asas ultimum remedium ini sangat dibatasi hanya pada delik formal tertentu, ${ }^{10}$ tidak terhadap seluruh delik formal. Hukum pidana dalam kejahatan lingkungan penerapannya digantungkan pada apakah sanksi administrasi telah dijatuhkan dan dijalankan atau tidak. Ancaman pidana atau sanksi pidana dalam UUPPLH Tahun 2009 lebih ringan dibandingkan yang diatur dalam KUHPidana. Hal ini tentu tidak memberikan efek jera (deterrence effect) selain tidak tegasnya penindakan dan penataan hukum lingkungan di Indoensia. ${ }^{11}$

Dalam arti yang luas, penegakan hukum termasuk preventif dan represif. Preventif adalah upaya agar tidak terjadi pelanggaran terhadap UUPPLH dimana upaya dapat dilakukan dalam bentuk negosiasi, dan supervise atau nasihat atau pendampingan. Adapun penegakan hukum represif adalah penegakan hukum untuk menyelesaikan perkara dalam hal ini kejahatan dibidang lingkungan hidup baik dari tingkat kepolisian, kejaksaan hingga pengadilan. ${ }^{12}$ Law enforcement atau penegakan hukum terhadap kejahatan lingkungan masih susah ditegakkan dikarenakan sulitnya mengumpulkan alat bukti dan menentukan definisi baku terhadap apa itu kerusakan lingkungan. ${ }^{13}$

Upaya penegakan hukum lingkungan hidup melalui hukum pidana adalah bagaimana tiga permasalahan pokok dalam hukum pidana ini dituangkan dalam Undang-Undang yang sedikit

\footnotetext{
${ }^{10}$ Terbatasnya asas ultimum remedium hanya pada delik tertentu yaitu pelanggaran terhadap baku mutu udara ambien, baku mutu air , baku mutu air laut atau kriteria baku kerusakan lingkungan hidup (Pasal 98 UUPPLH 2009) menurut penulis justru suatu kemunduran dari upaya kita untuk menciptakan sistem hukum lingkungan hidup Indonesia yang kuat. Dan juga sebagai bentuk kemunduran dalam pilihan politik hukum lingkungan hidup Indonesia.

${ }^{11}$ Daud Silalahi, Manusia Kesehatan dan Lingkungan, JurnalMasalah Lingkungan Hidup, Mahkamah Agung RI,1994, hlm. 1

${ }^{12}$ Dyah Adriantini Sintha Dewi, Konsep Pengelolaan LingkunganHidup, Menuju Kemakmuran Masyarakat, JurnalFakultas Hukum, Vol. 1 No. 1 Tahun 2012, UniversitasMuhammadiyah Magelang

${ }^{13}$ Sutrisno, Politik Hukum Perlindungan dan Pe-ngelolaanLingkungan Hidup, Jurnal Hukum, No. 3 Vol. 18 Juli2011, FH UII, hlm. 444-464
} 
banyak mempunyai peran untuk melakukan rekayasa social (social engeneering) ${ }^{14}$, dalam hal ini adalah perumusan aksi pidana, pertanggung jawaban dan sanksi pidana. Hukum sebagai alat rekayasa sosial penting agar masyarakat menjadi tertib dan yang terpenting keberlangsungan lingkungan hidup menjadi lebih terjamin (sustainability. ${ }^{15}$

Sebenarnya sanksi pidana terhadap kejahatan lingkungan hidup telah etrtuang dalam Pasal 187, 188, 202, 203, 502 dan 503 KUHPidana. Namun kemudian mengingat pentingnya pengaturan mengenai kejahatan terhadap lingkungan ini lebih dirinci dan dijabarkan lagi, dituangkalah kemudian di UUPPLH. Kejahatan terhadap lingkungan tidak hanya ada dalam UUPPLH dan KUHPidana namun juga pada perundangan lainnya antara lain UU No.5/1960 tentang UUPA, UU No.11/1967 Tentang Pertambangan, UU No.1/1973 Tentang Landasan Kontinen Indonesia; UU No. 11/1974 Tentang Pengairan, UU No.5/1983 Tentang Zona Ekonomi Ekslusif (ZEE) Indonesia, UU No.5/1984 Tentang Perindustrian, UU No. 9/1985 Tentang Perikanan. Selain itu ada pula diatur dalam UU No. 5/1990 tentang Konservasi Sumber DayaAlam Hayati dan Ekosistemnya; UU No.41/1999 Tentang Kehutanan, dan UU No 7/2004 Tentang Sumber Daya Air.

Banyaknya pengaturan mengenai kejahatan lingkungan hidup di berbagai peraturan perundang-undangan menyebabkan para penegak hukum terutama aparatur penegak hukum kepolisian harus bekerja lebih keras dan cermat. Untuk itu perlu membekali diri dengan keilmuan yang mumpuni, pihak Kepolisian tidak boleh salah dalam menyangkakan pasal terhadap tersangka agar para pelaku kejahatan terhadap lingkungan dapat dihukum sebagaimana kejahatan yang dilakukan. Ini tidak lain dimaksudkan agar tegak penegakan hukum pidana dalam bidang lingkungan hidup, dibutuhkan penerapan terhadap asas-asas kebijakan hukum pidana.

\section{Implikasi Politik terhadap Penegakan Hukum Pidana Dalam Undang-Undang Nomor 32 Tahun 2009 (Tentang Perlindungan dan Pengelolaan Lingkungan Hidup) dan RUU KUHP terhadap UPaya Penegakan Hukum Lingkungan Hidup Indonesia Pada Masa yang Akan Datang.}

Uraian dalam bagian ini hanya menyoroti secara normatif tindak pidana lingkungan hidup yang telah ada dalam RUU KUHP, yang menjadi catatan pada masa depan menjadi salah satu produk politik hukum, dan didalamnya juga ikut mengatur masalah hukum lingkungan. Ada beberapa hal yang harus diperhatikan dalam RUU KUHP mengenai rumusan tindak pidana lingkungan hidup, di dalam Pasal 192 Buku 1 RUU KUHP terdapat istilah pencemaran dan perusakan lingkungan yang berarti pencemaran lingkunga adalah masuknya atau dimasukan makhluk hidup, zat, energi dan/atau komponen lain ke dalam lingkungan hidup karena kegiatan manusia sehingga kualitasnya menurun, hingga ditingkat yang menyebabkan tidak berfungsinya peruntukan lingkungan hidup.

\footnotetext{
${ }^{14}$ Nyoman Serikat Putra Jaya, 2005, Kapita Selekta HukumPidana, Semarang: Badan Penerbit UNDIP, hlm. 253

${ }^{15}$ Helmi, Hukum Lingkungan dalam Negara Hukum KesejahteraanUntuk Mewujudkan Pembangunan Berkelanjutan,Inovatif; Jurnal Ilmu Hukum, Vol 4. No. 5 Tahun2011, hlm. 93-103
} 
Selanjutnya pada definisi perusakan lingkungan hidup yang terdapat pada Pasal 200 RUU KUHP mendefinisikan bahwa perusakan lingkungan hidup adalah tindakan yang menimbulkan perubahan langsungatau tidak langsung terhadap sifat fisik dan/atau hayatinya yang mengakibatkan lingkungan hidup tidak berfungsi lagi dalam menunjang pembangunan berkelanjutan kedua pengertian ini mencantumkan kata lingkungan hidup berkali-kali tetapi tidak ditemukan pengertian apa yang dimaksud dengan lingkungan hidup dan dari segi perumusan dan cakupan pengertian terdapat beberapa catatan.

Rumusan yang terdapat pada Pasal 200 mengenai definisi perusakan lingkungan menimbulkan tanda tanya di kata "Pembangunan berkelanjutan" yang digunakan menjadi tujuan saat dilakukan pemulihan fungsi lingkungan hidup. Pembangunan berkelanjutan pada Pasal ini menjadi dasar dilarangnya aktifitas perusakan lingkungan hidup RUU KUHP. Sebenarnya konsep Pembangunan Berkelanjutan masih kontroversi karena mendukung dan melegitimasi perkembangan pertumbuhan ekonomi kapitali, ini jadi permasalahan tersendiri yang menjadi serius karena Indonesia bukanlah negara kapitalis.

Selain itu, kejahatan terhadap lingkungan hidup yang diatur dalam Pasal 384 hingga 390 RUUKUHP dikategorikan sebagai kejahatan umum atau yang disebut sebagai generic crimes. Namun hanya mengenai kejahatan lingkungan dan tidak mengakomodir kejahatan dalam pengelolaan sumber daya alam lainnya seperti yang terdapat pada Undang-Undang Minyak dan Gas Bumi, Undang-Undang Pertambangan, Undang-Undang Kehutanan, Undang-Undang Sumberdaya Air, Undang-Undang PA, Undang-Undang Sumber Daya Alam Hayati dan Ekosistemnya, dan Undang-Undang Perkebunan. Mengapa kejahatan sebagaimana yang dimaksud dalam peraturan perundangan tersebut tidak dibuat agar tidak menghasilkan RUU KHUP yang tebal.

RUU KUHP menyamakan sanksi untuk pelaku perusakan atau pencemaran lingungan hidup yang memiliki dampak kecil dengan yang memiliki dampak besar, artinya perumusan Pasal ini menggunakan pola rumusan Pasal untuk tindak pidana materiil. Ini dikarenakan yang digunakan rumusan Pasal tindak pidana materiil maka tidak ada pembedaan kejahatan. Seharusnya tidak seperti ini mengingat karakteristik yang berbeda dari kualitas dan kuantitas pencemaran lingkungan terutama yang menggunakan teknologi. Terlebih kejahatan dengan memanfaatkan perkembangan teknologi saat ini tambah marak. Pembedaan terhadap sanksi dihadapkan pada akibat perbuatan, sangat penting, dan hal itu adalah upaya menanggulangi, hal tersebut penting dilakukan penggolongan terhadap skala dampak dari perusakan dan pencemaran lingkungan hidup. Dari skala tersebut dapat ditarik besar kecilnya sanksi kepada pelaku perusakan dan pencemaran lingkungan.

Selain hal di atas, permasalahan lain adalah tentang digunakannya istilah "Memasukan bahan". Persoalannya terletak pada ketiadaan penggolongan bahan, sebagai contoh diambil Pasal 386 dan Pasal 388. Rumusan pada dua pasal tersebut tidak jelas memberikan keterangan mengenai penggolongan dan ukuran jenis bahan. Terkait itu ada juga contoh lain, pada Pasal 390 hanya menjelaskan bahwa bahan adalah "Tidak hanya bahan makanan tetapi meliputi pembersih rumah tangga, kosmetik, dan lainnya". Pasal ini hanya dapat menjerat perbuatan "Memasukan bahan". Pasal ini tidak menggolongkan jenis bahan berdasarkan akibat atas tindakan, sehingga besar atau kecil akibat yang dilakukan atas tindak pidana yang 
dimaksudkan pada pasal ini, sanksi pidananya sama, tidak ada pembeda. Seharusnya rumusan Pasal 390 diikuti penjelasan rinci mengenai pengkategorian sebagaimana yang diatur dalam PP No.19/1999 tentang Penggelolaan Limbah B3.

Ada beberapa hal yang belum dicantumkanRUU KUHP dalam ruang lingkup tindak pidana lingkungan hidup. Pertama, menurut Pasal 384 ayat (2), 385 ayat (2), 386 ayat (2) dan 387 ayat (2), pidana dengan pemberatan hanyaditujukan terhadap perbuatan yang mengakibatkan orang mati atau luka berat. Di sisi lain, pencemaran maupun perusakan berat terhadap lingkungan tidak ditaruh atau diposisikan sebagai tindak pidana dengan pemberatan.

Kedua, hukuman denda yang diberikan tidak menunjukan fungsi kemanfaatan hukum. Hal ini dikarenakan pidana denda yang diancamkan pada pelaku perbuatan perusakan dan pencemaran lingkungan hanya terbatas pada denda atas perbuatan. Tidak diatur mengenai penjatuhan hukuman denda untuk biaya perbaikan atau penyembuhan dampak sosial dan dampak ekonomi atas akibat dari pencemaran dan perusakan lingkungan yang dilakukan. Ini sesuai dengan pendapat Barda Nawawi ${ }^{16}$ menyatakan bahwa pencemaran terhadap lingkungan tidak berdampak hanya kepada lingkungan fisik namun termasuk lingkungan non fisik. Tetapi, penafsiran tentang criteria dampak negatif terhadap sosial budaya sangat terbatas dan dogmatis 15 sehingga belum menyentuh ke persoalan kehancuran nilai masyarakat lokal akibat pencemaran atau perusakan lingkungan. Kebijakan Hukum Pidana dalam Upaya Penegakan Hukum Lingkungan Hidup Menurut Barda Nawawi ${ }^{17}$, harus ada kriteria yang jelas mengenai pencemaran sosial budaya karena sebenarnya pencemaran tidak terbatas pada pencemaran dan perusakan fisik lingkungan namun dalam hal ini juga sosial budaya seperti penyebaran paham komunis, pengajakan umat untuk meninggalkan agamanya bahkan penodaan agama.

Tidak diakomodirnya mengenai pengenaan sanksi terhadap perusak dan pencemaran sosial budaya akan mencederai keadilan lingkungan yang mencakup banyak aspek dalam hal ini terutama norma budaya, kebiasaan, keputusan, kebijakan yang berkelanjutan. Padahal menurut RUU KUHP, dalam mempertimbangkan hukum yang akan diterapkan, hakim sejauh mungkin mengutamakan keadilan di atas kepastian hukum (Pasal 12). Ketiga, tindak pidana terhadap lingkungan hidup hanya menjangkau kasus-kasusu perusakan dan pencemaran lingkungan hidup di wilayah perkotaan yang cenderung dilakukan oleh industri perkotaan seperti melakukan pencemaran terhadap pompa air, sumur, kelengkapan air minum, mata air, dll yang dipakai untuk umum Bersama dengan amsyarakat lainnya (Pasal 386, 387, 388, 399 RKUHP). Pasal-pasal tersebut belum menggapai tindakan perusakan dan pencemaran du bidang perkebunan seperti sawit, kehutanan, baik dilakukan secara sengaja maupun tidak disengaja.

Keempat, sanksi pidana terhadap pelaku perusakan dan pencemaran lingkungan hidup hanya pidana penjara dan denda. Seharusnya tidak hanya dua macam sanksi ini saja mengingat akibat yang ditimbulakn dari perusakan dan pencemaran lingkungan tidaklah kecil serta berdampak sistemik. Seharusnya diatur pula mengenai hukuman untuk melakukan

\footnotetext{
${ }^{16}$ Barda Nawawi Arief, "Masalah Penegakan HukumPidana Terhadap Tindak Pidana Lingkungan Hidup", JurnalMasalah-Masalah Hukum, No. 1 Tahun 1992, hlm. 24

${ }^{17}$ Ibid
} 
tindakan pemulihan terhadap rusaknya fungsi lingkungan serta ganti rugi untuk mengganti ongkos sosial karena dampak perusakan dan pencemaran lingkungan yang dilakukan.

\section{PENUTUP}

\section{KESIMPULAN}

a. Ada beberapa impliksai yang muncul akibat dimasukkannya penegakan hukum pidana dalam UUPPLH 2009 terhadap penegakan penegakan hukum lingkungan Indonesia hidup saat ini. Yaitu:

1) Pertama, UUPPLH 2009 mengenal pelaku tindak pidana selain manusia yaitu badan hukum atau perserikatan, yayasan, atau organisasi lainnya sedangkan menurut KUHP yang menjadi pelaku adalah hanya manusia pribadi;

2) Kedua, UUPPLH 2009 di samping menggunakan sanksi pidana pokok dan pidana tambahan seperti dalam KUHP juga menggunakan tindakan tata tertib dalam mempertahankan norma-normanya;

3) Ketiga, rumusan pemidanaan yang kabur dengan penggunaan kata "dan/atau", menyebabkan hakim dapat memilih antara penjatuhan sanksi kumulatif ataupun alternatif;

4) Keempat, UUPPLH 2009 memandang hukum pidana sebagai upaya terakhir (ultimum remedium) bagi tindak pidana formil tertentu, sementara untuk tindak pidana lainnya yang diberlakukan asas premum remedium (mendahulukan pelaksanaan penegakan hukum pidana).

b. Implikasi yang muncul akibat dimasukkannya penegakan hukum pidana dalam UUPPLH 2009 dan RUU KUHP nantinya terhadap penegakan penegakan hukum lingkungan Indonesia hidup pada masa yang akan datang. Terkait dengan pilihan politik hukum yang kita lakukan tersebut, yang pertama adalah dimasukkannya penegakan hukum pidana dalam UUPPLH 2009 yang memiliki beberapa kelemahan seperti penulis jabarkan pada kesimpulan identifikasi masalah pertama akan semakin rumit pula nantinya upaya penegakan hukum lingkungan di Indonesia dengan dimasukkannya ketentuan-ketentuan penegakan hukum pidana kedalah KUHP. Maka ini dapat menjadikan penegakan hukum pidana pada lingkungan kedalam KUHP maka akan menghilangkan status lex specialis-nya, dan ini akan menambah kerumitan dan kompleksitas dalam upaya mewujudkan penegakan hukum pidana lingkungan di Indonesia pada masa yang akan datang.

\section{SARAN}

a. Pertama, perlunya pembenahan pola pemidanaan dan sanksi pidana dalam UU PengelolaanLingkungan hidup yang memiliki nilai-nilai kepastian hukum dan nilainilai keadilanyang ditegakkan oleh semua pihak, kedua perlunya pembenahan pola pemidanaan dan sanksi pidana dalam UU Pengelolaan Lingkungan hidup yang seharusnya sinkron dan konsisten dengan KUHP dan RUU KUHP di masa mendatang.

b. Beberapa kebijakan hukum pidana dalam penegakan hukum lingkungan hidup di masa mendatang yang perlu dilakukan Pertama, pola pendekatan pemidanan lingkungan 
mendatang adalah penjeraan (deterrence approach) atau lazim disebut dengan pendekatan penegakan hukum atau stick approach. Pendekatan ini paling banyak digunakan dalam kebijakan penegakan hukum lingkungan, kedua, upaya pembuktian diarahkan kepada delik formal dimana pembuktian hanya melihat pada unsur kelakuan yang dapat dilihat dengan unsur panca indera, misalnya tindakan pencemaran atau perusakan lingkungan hidup; ketiga, pemidanaan diarahkan pada sanksi kumulatif, artinya hakim dapat menjatuhkan seluruh ketentuan pemidanaan dalam undangundanglingkungan tersebut, baik digabung seluruhnya atau digabung 2 (dua) atau 3 (tiga) saja.

\section{DAFTAR PUSTAKA}

\section{Buku :}

Daud Silalahi, 1994, Manusia Kesehatan dan Lingkungan, JurnalMasalah Lingkungan Hidup, Mahkamah Agung RI

Daud Silalahi, 2001, Masalah Pengelolaan Lingkungan Hidup, Edisi Ketiga, Alumni, Bandung

David Kairsy (ed, 1990, The Politics of Law, A Progressive Critique, Pantheon Books, New York

Donella H. Meadows, 1980, Batas-batas pertumbuhan, diterjemahkan oleh : Masri Maris, Gramedia, Jakarta,

Jimly asshiddiqie, 2010, Green Constitution : Nuansa Hijau Undang-Undang Dasar Negara Republik Indonesia Tahun 1945, Rajawali Pers, Jakarta

Mahfud MD, 2012, Politik Hukum di Indonesia, Rajawali Pers, Jakarta, edisi revisi, cetakan ke-5

Mochtar Kusumaatmadja, 2011, Konsep-Konsep Hukum Dalam Pembangunan, Alumni, Bandung

Muhammad Erwin, 2007, Hukum Lingkungan : dalam sistem kebijaksanaan pembangunanLingkungan Hidup Edisi Ketiga, Refika Aditama, Bandung,

Nyoman Serikat Putra Jaya, 2005, Kapita Selekta HukumPidana, Semarang: Badan Penerbit UNDIP

Soedarto, 1986, Hukum dan Hukum Pidana, Alumni, Bandung

Syahrul Machmud,2011,Penegakan Hukum LingkunganIndonesia, Graha Ilmu, Yogyakarta

\section{Jurnal, Makalah Dan Majalah :}

Dyah Adriantini Sintha Dewi, Konsep Pengelolaan LingkunganHidup, Menuju Kemakmuran Masyarakat, JurnalFakultas Hukum, Vol. 1 No. 1 Tahun 2012, UniversitasMuhammadiyah Magelang

Sutrisno, Politik Hukum Perlindungan dan Pe-ngelolaanLingkungan Hidup, Jurnal Hukum, No. 3 Vol. 18 Juli2011, FH UII, hlm. 444-464

Helmi, Hukum Lingkungan dalam Negara Hukum KesejahteraanUntuk Mewujudkan Pembangunan Berkelanjutan,Inovatif; Jurnal Ilmu Hukum, Vol 4. No. 5 Tahun2011 
Barda Nawawi Arief, "Masalah Penegakan HukumPidana Terhadap Tindak Pidana Lingkungan Hidup”, JurnalMasalah-Masalah Hukum, No. 1 Tahun 1992

I.S Susanto, 1992, Pemahaman Kritis Terhadap Realita Sosial,MajalahMasalah-Masalah Hukum, Nomor 9 Tahun

Teuku Muhammad Radhie dalam majalah PRISMA, no. 6 tahun keI-II, Desember 1973

Edra Satmaidi, Politik Hukum Pengelolaan Lingkungan Hidup Indonesia, Makalah, 2010

Absori, Penegakan Hukum Lingkungan Pada Era Reformasi, artikel dalam Jurnal Ilmu Hukum, Vol. 8. No. 2, September 2005

Edra Satmaidi, "Politik Hukum Pengelolaan LingkunganHidup Di Indonesia Setelah Perubahan Undang-UndangDasar 1945”, Jurnal Konstitusi, Vol. 4 No. 1 Tahun 2011,FH Universitas Riau

\section{Peraturan Perundang-Undangan :}

Undang-Undang Dasar Negara Republik Indonesia

Undang-Undang Nomor 4 Tahun 1982 tentangKetentuan-Ketentuan Pokok PengelolaanLingkungan Hidup

Undang-Undang Nomor 23 Tahun 1997tentang Pengelolaan LingkunganHidup

Undang-Undang Nomor 32 tahun 2009 tentang Perlidungan dan Pengelolaan Lingkungan Hidup 